\title{
Criminological Organized Network Models of Human Smuggling: An Analysis with Special reference to the United Nations Convention on Transnational Organized Crime and the Protocol against Smuggling of Migrants
}

\section{Y. Kathirgamathamby*}

Department of Legal Studies, The Open University of Sri Lanka, Sri Lanka

\section{Abstract}

The Criminological Organized Network Model (CON Model), one of the theoretical models propounded by several scholars, postulates that the assignment of human smuggling is carried out by wellorganized international criminal networks. This model elucidates the objectives, the form, and the tasks carried out by organized criminal groups. The United Nations Convention on Transnational Organized crime 2000 (UNCTOC) and the Protocol against Smuggling of Migrants via Air, Sea and Land (HS Protocol) are the major international legal instruments governing human smuggling. Both these instruments state that human smuggling is a transnational crime committed by organized criminal groups. Against this background the main objective of the paper is to examine as to how far the features of the CON Model has been translated into international legal instruments particularly in Article 2(a) of the

*Correspondence should be addressed to Dr. Yasodara Kathirgamathamby, Department of Legal Studies, The Open University of Sri Lanka, Nawala, Sri Lanka

Email: ykath@ou.ac.lk

(D) https://orcid.org/0000-0002-6385-5271

(Received $9^{\text {th }}$ June 2021; Revised 13 ${ }^{\text {th }}$ December 2021; Accepted 20th December 2021 (C) OUSL)

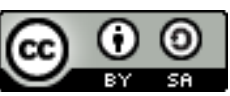

This article is published under the Creative Commons Attribution-Share Alike 4.0 International License (CC-BY-SA). This license permits use, distribution and reproduction in any medium; provided it is licensed under the same terms and the original work is properly cited. 
UNCTOC and Article 3(a) of the HS protocol in order to identify the gaps in the said articles and make recommendations for comprehensive legal provisions in line with the CON Model of human smuggling. Doctrinal research incorporating conceptual, descriptive, interpretative, analytical, and comparative methodology have been utilized in the research. The paper discusses and analyzes the objectives, nature, and tasks of organized crime groups relevant to the definition of an organized criminal group and human smuggling as per the UNCTOC and the HS Protocol and draws out gaps in these definitions. It can be noted that the definition of the organized crime groups fails to be sufficiently comprehensive. There is uncertainty in the human smuggling protocol read with UNCTOC as to whether people who help the human smuggling operation on humanitarian grounds are guilty or not. The paper, it is hoped, will contribute to the establishing of a more comprehensive definition of an Organized Criminal Group (OCG) and set out a clear demarcation and differentiation between people who act with profit-making motives and the sympathetic supporters.

Key words: Criminological Organized Network Model, UNCTOC, Human smuggling protocol, Organized Criminal Group

\section{Introduction}

Human smuggling can be defined as an illegal transnational movement through which people are taken from one state to another. Different modus operandi is used to carry out this enterprise. Smuggling through air, sea, and land are employed in the transportation of migrants. The crime is committed both by individuals as well as by criminal groups. Both smugglers and the migrants in addition to becoming collaborators and liable are the crucial parties involved in the criminal process

In the 1990s, the US, Western and Central Europe, and North America experienced a significant increase in the number of unauthorized arrivals of irregular migrants facilitated by human smugglers. Therefore, states have initiated several domestic and regional level counter measures. Gradually, such state-centric and regional initiatives have led to global action to develop international instruments. (McClean, 2007).

The major steps taken in this regard were the adoption of the UN Convention on Transnational Crime2000 (UNCTOC) and the Protocol against Smuggling of Migrants via Air, Sea and Land (HS Protocol). The HS Protocol and UNCTOC contain provisions for 
criminalizing human smuggling as well as for the protection of the rights of smuggled migrants. The UNCTOC defines what an Organized Criminal Group (OCG) is, and clarifies the different types of transnational organized crimes and national and transnational obligations of states parties, rights of the victims and witnesses etc. The HS protocol defines human smuggling and lists out the crimes connected with human smuggling, such as documents fraud, and explains the obligation of states parties, the rights of smuggled migrants, and mutual legal assistance between states etc.

Parallel to the deliberation on international legal instruments, a set of scholars have attempted to develop theoretical models on human smuggling based on empirical evidence across the globe. These models can be categorized as the Business Model, Human RightsBased Model, Criminological and Organized Network Models, Estimates of Flow, Mode of the Crossing, and the Likelihood of Apprehension Models. In addition, there have been other developments such as the Gender Approach, Global Comparative and Structural Approach, Labor Demand and Supply, and Deterrence Theory Models. While several models have been conceived, it is nevertheless to be appreciated and recognized that these are all interrelated and interdependent. They fall within the overall ambit of the human smuggling process and reflect the different facets of this considerably complex operation.

This paper focuses on the Criminological, Organized Network Model (CON Model) which examines the objective, nature, characteristics, and tasks of the organized criminal groups. The CON model has presented diverse views regarding the objective, nature,

characteristics, and tasks of the organized criminal groups. This paper mainly focuses on the extent such diverse research findings of CON model are reflected in both the Article (2a) of UNCTOC, and the Article 3(a) of the HS protocol in order to comprehend the lacuna and to suggest making comprehensive legal provisions in line with the CON Model of human smuggling.

The paper first sets out the objective of the study and outlines the methodology used. Thereafter, the discussion is presented in three parts. The first part of the paper elaborates an examines the model in detail, and the second part of the paper explains the definition of Organized Criminal Group (OCG) under Article 2 (a) of the UNCTOC, and the definition of human smuggling under Article 3(a) of the HS protocol and other relevant provisions of both instruments. In addition, this part provides a comparative analysis to affirm the extent UNCTOC and the HS protocol are the fundamental components of the CON model. The final section which concludes the study seeks to set out the key findings. 


\section{Objective of the study}

The objectives of the paper are as follows.

- To identify the main characteristics of the of the CON model

- To describe the features of the CON model and

- To compare and contrast the features of the CON Model and Article 2(a) of the UNCTOC and Article 3 (a) of the HS protocol in order to suggest amendments to existing legal provisions.

\section{Materials and Methodology}

The doctrinal research method was used in this study which is a genre of research in the legal field most suited to the objective of this study. Also known as theory-testing research, it deals with analytically studying existing laws, related cases and authoritative materials on some specific matter. Under the doctrinal method, conceptual, analytical, interpretative, and comparative methodologies were adopted. Conceptual analysis was used to describe and explain the indispensable meaning of the CON model and different facets of the model. The analytical and interpretative methodology is used to describe and explain the relevant articles in the UNCTOC and the HS protocol. The comparative methodology is employed to ascertain how far the underpinning of the CON model is mirrored in the international instruments namely the UNCTOC and the HS Protocol.

The UNCTOC and the HS Protocol have been used as primary data. Books, journal articles, reports of the United Nations Office on drugs and Crime, guidebooks, web resources have been analyzed as secondary data.

\section{Scope of the Study}

Several studies indicate that although both organized criminal groups and organized criminal gangs share common features there are dissimilarities between these two. In broader context organized criminal gangs commit transnational crimes, drug smuggling, human trafficking and terrorist activities, whereas the organized criminal groups particularly do not engage in terrorist activities. This paper is restricted only to organized criminal groups that involve transnational crimes, particularly human smuggling. 


\section{Findings and Discussion}

\section{Criminological, Organized Network Model and Human Smuggling}

According to the EU, the transnational criminal organizations collaborate with more than two people to commit serious crimes for the purpose of obtaining financial benefit. (Holmes, 2015). The German Police defined the OCG as 'any group of people who have consciously and deliberately decided to co-operate in illegal activities over a certain period of time, apportioning tasks among themselves and often using modern infrastructure systems, with the principle aim of amassing profits as quickly as possible' (German Police, 1992). Another definition given by the Interpol's Organized Crime Unit is: 'any group having a corporate structure whose primary objective is to obtain money through illegal activities, often surviving fear or corruption' (Interpol, 1992). The Canadian criminal code defines the OCG as:

"a group of three or more people whose purpose is the commission of one or more serious offences that would likely result in the direct or indirect receipt of a material benefit, including a financial benefit, by the group."

\section{Nature of human smuggling networks}

A group of scholars have attempted to theorize the nature of the organized criminal smuggling networks. Human smuggling networks have numerous characteristics. Some groups may claim all the features while some may just fit in to just a couple. (Samuel, 2003, 2004).

Several studies reveal that human smuggling is committed by well organized criminal groups. John Salt and Jeremy Stein state that 'smuggling of migrants is an established branch of a well-organized international gangster syndicate' (2000). One such example is the Big 'Snakehead', the Chinese human smuggling network. Such organized human smuggling criminal networks are sophisticated (Samuel, 2003, 2004; Anastasia 2004) having a hierarchical structure (Salt \& Stein 1997), and clear division of labor among the members of the organization (Zhang, 2008). Theodore Baird states that the Organized Crime Model involves a control structure where a centrally placed 'smuggler' dishes out commands and enforces the rules in a social hierarchy' (Baird, 2011).

Alternatively, certain studies indicate that there are loose networks that have no clear command structure, working with flexibility and are united on an ad-hoc basis (Kung, 2000). These groups sign agreements/contracts when and if necessary and finish their task 
(UNODC, 2011). Once they finish the tasks the groups dissolve. Kung (2000) also verifies that criminal groups are undeniably far more cellular in structure with loose connections made and broken all the time with more subtle hierarchies.

Organized criminal groups involved in human smuggling are active in other serious crimes such as human trafficking, document fraud, money laundering, drug trafficking and corruption, smuggling of firearms, drugs, stolen vehicles and other illicit goods (Salt \& Stein 1997,). Another study (Myrianne Coen (ed.), 2011) too postulates human smuggling as a criminal act committed by well-organized networks with links to other transnational crimes. Examples are the Hungarian based criminal group, 'Snakeheads' based in China; mafia groups in the United States and Italy; Big' coordinating agent in Pakistan; and the Chinese 'Fuk Ching'. These are well established criminal networks facilitating human smuggling with other transnational organized crimes (Cleo, 2000; Zhang, 2008; Kung, 2000). The scope of this research paper is however limited to human smuggling.

Another notable feature of these OCGsis that they have and use ethnic, religious and social links to achieve their tasks. These ties are important to establish working relationships in illegal activities (Smith \& Papachristos, 2016; Von Lampe \& Johansen, 2004). The United Nations Office on Drugs and Crime (UNODC) states that smugglers are often ethnically linked to the territories where they operate or share ethnic or linguistic ties with the migrants they smuggle (EPRS, 2021). Some other authors too favored the notion of social ties. Zhang (2008) in his book, titled Chinese Human Smuggling Organizations, Families, Social Networks, and Cultural Imperatives argues that social networks play a big role in the entire human smuggling operation.

Herman (2006) also supports this aspect and has added the familial model to the Criminological, Organized Network Model. In her view, smuggling networks operations are facilitated by family, friends and relative circles. Although both Zang (2008) and Herman (2006) agree with the point that the social network play a significant role they differ in one aspect. The former claims that social networks facilitate the journey in terms of payment and provide amenities in the destination, whereas the latter finds that social networks act as the middleman helping the smugglers to search out prospective clients.

The EU also points out that the members of the OCGs have casual association through social and family contacts. These ethnic, religious and social networks are scattered in the transit and destination 
countries. They support the operation by paying the necessary fee or down payment, and by providing food and shelter.

Naylor says that smuggling OCGs are different to other criminal groups as they have a special knowledge about the business and are a durable hierarchical structured organization. He further notes that these groups use violence and corruption. They also contribute to the global economy (Naylor, 2002).

Terrorist groups also engage in criminal activity like drug trafficking and human smuggling to finance their operations (Mincheva \& Gurr, 2006; Lanzante, 2009). For example, in Sri Lanka, the Liberation Tigers of Tamil Eelam (LTTE) have been involved in human smuggling (Berry et al., 2003). Another example is that of the Mexican drug cartel an OCG which engaged in human smuggling had connections with terrorist organizations. (Kimery, 2000)

\section{Objective of the Organized Criminal Groups}

The main objective of the OCGs is gaining profit out of the human smuggling venture. Many studies prove this fact. Salt and Stein identify Criminological, Organized Network Model (CON model) as an example and theorize human smuggling as a business composed of legitimate and illegitimate markets in which actors pursue profit and commercial gain (Salt \& Stein 2000). Veronika Bilger (2006) also agrees that the human smuggling operators make profit out of this transnational service industry. The main beneficiaries of the business are the destination country employers, smugglers and officials from source countries (Kung, 2000). As per Bilger, the smugglers are perceived as service providers and the migrants as clients. As a European Commission study (2015) on migrant smuggling states: 'smuggling is a supply and demand driven businesses. The International Organization for Migration (IOM) states that for organized crime groups, smuggling people across borders is a "lowrisk, high-profit" business.

As per Kyle \& Koslowski, (2011), close to 50 million persons across the globe have been smuggled, with financial returns of beyond \$3.5 billion per year. In 2015, human smuggling criminal networks had an estimated turnover of between $€ 3$ and $€ 6$ billion (Europol, 2019). Furthermore, migrant smugglers made an estimated $€ 190$ million in revenues in 2019 on the western, central and eastern Mediterranean routes alone (Europol, 2019). Although many studies found that the objective of the OCG is profit making, some studies have found that family members, relatives and social networks provide different services to the smugglers and migrants free of charge. (Herman 2006; Zhang 2008). 


\section{Tasks of the Organized Criminal Groups}

The OCGs assign their tasks among the members of the group. In human smuggling groups there are three grades or divisions. These three categories can be further divided as permanent and nonpermanent members. Generally, the top-level leaders are the permanent members. The intermediaries and low- level members are ad-hoc or non-permanent. They include public officials, family, friends, social networks, and in few instances, other terrorist groups.

The Australian Institute of Criminology points out ten different categories of people that are engaged in a single smuggling process (Bajrektarevic, 2000). One study by Zhang (2008) proves that the Chinese organized criminal group called 'Snake Heads 'assign the tasks among the recruiter, document vendor, payment collector, coordinator, transporter, arranger of fraudulent business delegation, securer of deposit, escort, fraudulent marriage arranger, guard, arranger of travel, guarantor, leaser of boats, receiver of clients, corrupt officials, arranger of stowaways, and student visa fraud organizer. These are described as the important parties of the groups as bridge builders and service providers (Zhang, 2008), Edward Kleeman (2007). The bridge builders build territorial and social bridges and operate at a global and inter-ethnic level, accept a key role in organized crime. The facilitators are service providers who give a wide range of important services such as, enrolling potential migrants, collecting cash from them, and arranging forged documents, transporting migrants to the other borders, taking care of the migrants during the voyage (in the case of maritime smuggling; this is important), sorting out the organizing tasks and coordinating the sub procedure between them. This group includes safe house administrators, overseers, and debt collectors both in the source country and in the destination.

Public officials from source, transit and destination also have major tasks in the human smuggling process. As stated above, these public officials are ad-hoc members in the OCGs. The process of human smuggling cannot be smoothly executed without the support of the law enforcement officials. According to the UNODC, the public official in some countries have also been implicated in facilitating irregular migration and enabling their stay (2011). The same view has been supported in some other studies as well. For example, Law enforcement officials at different points assist human smuggling by performing different tasks connected to their role.

The law officials include border control officials, police forces, soldiers, immigration officials, embassies or consulate employees (Zhang, 
2008). They are well paid for their work. The UNODC also notes that certain public officials of the highest-level and politicians also take part in maritime smuggling (2015).

\section{Criminological, Organized Network Models of Human Smuggling, United Nations Convention on Transnational Organized Crime and the Protocol against Smuggling of Migrants Via Air, Sea and Land}

The UNCTOC and the Protocol are the major developments that seek to handle the issue of human smuggling. According to Article 37(4) of the UNCTOC:

'any protocol to this convention shall be interpreted together with this convention taking into account the purpose of that protocol'.

In this context the analysis of relevant provisions of the Protocol directs focus on substantial provisions of the UNCTOC.

The CON model indicates that smuggling networks are present in multiple states and they commit transnational organized crimes (Salt \& Stein 1997; Zhang 2008; Herman, 2006). Regarding this point, it is to be noted that although the convention is titled as the Convention on Transnational Organized Crime and the objective is criminalizing Transnational Organized Crime (TOC), the term TOC is not defined in the convention. There was a serious discussion on agreeing upon a universal definition on TOC. However, considering the diverse legal traditions and systems of the world, it was difficult to agree on a universal definition on TOC. This is seen as a drawback of this convention.

Article 2 (a) defines the term OCG, for the purposes of this convention, as:

"Organized Criminal Group" shall mean a structured group of three or more persons existing for a period of time and acting in concert with the aim of committing one or more serious crimes or offences established in accordance with this convention, in order to obtain, directly or indirectly, a financial or other material benefit."

Article 3(a) of the Protocol defines human smuggling as follows:

"Smuggling of migrants" shall mean the procurement, in order to obtain, directly or indirectly, a financial or other material benefit, of the illegal entry of a person into a State Party of which the person is not a national or a permanent resident; 
Article 2(a) of the UNCTOC and Article 3(a) of the HS protocol should be read together. Thus, human smuggling should be viewed as being committed by an OCG. With this backdrop, the following sections will analyze how far the above definitions in the UNCTOC and the HS protocol reflect the elements of the CON Model.

\section{The term structured group}

The foremost element in the definition is a "structured group". Article 2 (c) UNCTOC defines the term structured group as follows:

"Structured group shall mean a group that is not randomly formed for the immediate commission of an offence and that does not need to have formally defined roles for its members, continuity of its membership or a developed structure".

The definition fails to provide clarity regarding the meaning of what is a structured group. As per the definition, OCG should be a "structured group". The above discussion on the nature of CON model asserts that organizational patterns of human smuggling groups vary. As per the said model there are different typologies of groups engage in human smuggling activities. Hence, there is an uncertainty in definition whether all these types of criminal groups would fit within the definition of structured group.

\section{The Phrase 'period of existence'}

The second important aspect in Article 2 (a) of the UNCTOC is the period of existence. Article 2 states that in order to be categorized as an OCG, the group should exist for a period of time. However, the provision has failed to explain what the period of existence is. This is also seen as a shortcoming in the convention. The CON model reveals that there are some groups which operate for a long time (Example: The Chinese Snakeheads which originated in 1980), and some are adhoc groups. In 2009 four persons had arranged a smuggling operation from Thailand to Canada to illegally transport around five hundred (500) Sri Lankans (Appulonappa v Canada 2015, SCC.). This is an illustration to assert than ad-hoc criminal groups also succeed in the areas of criminal operation. In this context, it is understandable that many groups do not fulfill the requirement of period of existence as per the UNCTOC.

\section{Financial or other material benefit is a significant feature}

The third element in both Article 2(a) and 3(a) of the protocol is "financial or other material benefit." The objective of the OCG is gaining profit. The financial element is a core factor to prove the offence of human smuggling. (Kathirgamathamby, 2016) The 
inclusion of financial motivation in the HS Protocol achieves two important tasks, (a) it does not punish facilitating illegal entry for humanitarian purposes (b) it opposes the deception that all border crossings are clearly lawful or unlawful. However, the Protocol does not provide a clear solution to acts based on humanitarian aspects. The UNODC has explicitly stated that the protocol does not 'criminalize family members, non-governmental or religious groups that facilitate the illegal entry of migrants for humanitarian or nonprofit reasons' (McAdam \& Baumeister, 2010).

The CON model emphasizes that the objective of the criminal groups is profit making. The profit makers are smugglers, employers, immigrant agents, and the corrupt public officials. Part one of this paper reveals that the smuggling operations are assisted by family, friends and relatives free of charge.

The analysis of the UNCTOC and the protocol discloses two distinct points. On the one hand article 2 of UNCTOC emphasizes that 'OCG' does not contain groups that do not seek to gain any 'financial or other material benefit'. On the other hand, based on humanitarian grounds, the protocol does not aim to punish the people who helped the migrants. As required by article 37(4) of the UNCTOC, article 2(a) and article 3(a) of the protocol should be read together. In doing so it is unclear whether people involved in smuggling operation on humanitarian grounds will be guilty of human smuggling or not.

\section{Terrorist Groups and human smuggling}

Preamble of the UNCTOC notes that there are links between transnational organized crime and terrorist crimes. However, UNCTOC does not intend to include the terrorist and insurgent groups in the definition of OCG as that their aims are entirely different (UNODC, 2011). Yet the CON model reveals that OCGs have links with terrorist groups and some terrorist groups commit human smuggling. Hence, it is not clear as to whether human smuggling operations carried out by a terrorist organization is a transnational organized crime as per the convention.

\section{Conclusions}

The purpose of the of the research study was to find out how far the UNCTOC represents the views expressed under the CON model that are in the UNCTOC and the Protocol. The study reveals that the UNCTOC does not define the term TOC and, also the definition of OCG. Article 2(a) fails to cover various types of groups that commit transnational crimes including human smuggling. It therefore fails to be comprehensive. Also, Article 2(c) the UNCTOC does not answer what a structured group is. Furthermore, article 2(a) fails to specify 
what the period of existence of an OCG is in order for it to be categorized as one. Moreover, both the UNCTOC and the protocol fall short of giving a clear answer as to whether intermediaries who take part in the human smuggling operation on humanitarian grounds will be guilty of the crime of human smuggling. These findings can contribute to establishing a comprehensive definition of an OCG and to setting out a clear demarcation between people who act with profitmaking motives, and sympathetic supporters. Taking into account, all these findings, this paper suggests that the international community has to work towards formulating more comprehensive provisions consistent with the different facets of the CON model.

\section{References}

Bajrektarevic, A. H. (2000). Trafficking in and smuggling of human beings - linkages to organized crime - international legal measures, Krinrinologijuisot'i.julnaintegracija. 8 (2@0) Br. 5"7$70,57-70$. https://core.ac.uk/download/pdf/14459087.pdf

Berry, L. B., Curtis, G., Hudson, R., Miro, R., Gibb, J. N. \& Karacan, T. (2003). Nations Hospitable to Organized Crime and Terrorism. https://www.hsdl.org/homesec/docs/dod/nps06-0218041.pdf\&code $=66 e a 90 c 4 a b 28058 f 6630 b f 76 f 8 e 39 b 7 d$

Bilger, V., Hofmann, B. \& Jandl, M. (2006). Human Smuggling as a Transnational, Service Industry: Evidence from Austria, International Migration, 44(4), 59-93. https://doi.org/10.1111/j.1468-2435.2006.00380.x

Duijn, P. A. C. (2016). Detecting and Disrupting Criminal Networks: A Data Driven Approach, (PhD Thesis), University of Amsterdam. https: / / dare.uva.nl/search?identifier=447f10ad-cecf-4b959f8b-7cb97e84eac0citations

Europal, (2021). Understanding EU action against migrant smuggling. European Parliamentary Research Service, PE 659, 450. https://www.europarl.europa.eu/RegData/etudes/BRIE/2021 /659450/EPRS_BRI(2021)659450_EN.pdf

European Commission, DG Migration \& Home Affairs (2015). A study on smuggling of migrants, Characteristics, responses and cooperation with third countries Case Study 2: Ethiopia - Libya - Malta/Italy.

researchgate.net/publication/335369172_Study_on_smuggling _of_migrants_Characteristics_responses_and_cooperation_with_ 
third_countries_Case_Study_2_Ethiopia_-_Libya__MaltaItaly/citations

Herman, E. (2006). Migration as Family Business, the role of personnel networks in the mobility phase of migration. International Migration, 191-230.

https://doi.org/10.1111/j.1468-2435.2006.00384.x

Holmes, L. (2015). Advanced Introduction to Organized Crime, Edward Elgar Publication.

Kathirgamathamby, Y. (2016). Human Smuggling-Implications on Rights of Migrants: An Examination from the Standpoint of International Law, OUSL Journal, 10, 93-114. https://doi.org/10.4038/ouslj.v10i0.7337

Kimery, A. (2009). Unholy Trinity. Homeland Security. Today, Magazine. 24- 36.

http://ipaperus.ipaperus.com/HomelandSecurityToday/Augus t2009/

Kleemans, R. (2007). Organized Crime, Transit Crime, and Racketeering, Crime and Justice, 163-215. htpps://doi.org/ 10.1086/501509

Kung, C. (2000). Supporting the Snakeheads: Human Smuggling from China and the 1996 Amendment to the U.S. Statutory Definition of Refugee. Journal of Criminal Law and Criminology, 1271-1316 https://scholarlycommons.law.northwestern.edu/cgi/viewcont ent.cgi?article $=7063 \&$ context $=$ jclc

Lampe, K. V. \& Johansen, P. O. (2004). Organized Crime and Trust: On the conceptualization and empirical relevance of trust in the context of criminal networks, Global Crime, Taylor \& Francis Journals, 6(2), 159-184.

DOI: $10.1080 / 17440570500096734$

Lanzante, Joseph A. (2009). The Relationship between criminal and terrorist organizations and human smuggling (Unpublished Master Thesis, Naval Postgraduate School! Monterey, California, https: / / www.hsdl.org/ ?view\&did=29533 citations

McClean, D. (2007). Transnational Organized Crime; A commentary on the UN Convention and Its Protocols, Oxford University press. 
Myrianne, C. \& Nato, O. (2011). Human trafficking, Smuggling and Illegal immigration: International Management by Criminal Organizations, Amsterdam: IOS Press.

Naylor, T. (2002). 'Mafia's myths and markers: on the theory and practice of enterprise crime'.

http://imumi.org/attachments/article/97/UNODC_Smuggled_ Migrants_2010.pdf

Parliamentary research unit, Definitions of Organized Criminal group https://static.pmg.org.za/docs/1998/981020definitions.htm.

Salt, J. and Stein, J. (2000). Trafficking and Human Smuggling: A European perspective. International Migration, 31-56. https://library.fes.de/libalt/journals/swetsfulltext/8525728.p df

Samuel, L. (2003/2004). 'Smuggling of Refugees by Sea: A ModernDay Maritime Slave Trade, 2 Regent. J. Int'l L., 1(2), 1-28.

Theodore, B. (2013). 'Theoretical Approaches to Human Smuggling', DISS Working paper.

https://www.files.ethz.ch/isn/170120/WP2013-

10_ted\%20baird_human\%20smuggling_web.pdf

UNODC,Travex

preparatory455https://www.unodc.org/pdf/ctoccop_2006/0460074_ebook-e.pdf citations

UNODC, (2015). Catalogue of Materials against Trafficking in Persons \& Smuggling of Migrants. https://www.unodc.org/documents/humantrafficking/UNODC_Catalogue_of_Materials.pdf, citations

UNODC (2011). In-depth training manual investigating and prosecuting the smuggling of migrants.

https://www.unodc.org/unodc/en/humantrafficking/migrant-smuggling/in-depth-training-manual-onsmuggling-of-migrants.html, citations

UNODC (2015) Migrant smuggling in South Asia currently trends and challenges.

https://reliefweb.int/report/world/migrant-smuggling-asiacurrent-trends-and-related-challenges-enmy, citations

UNODC (2011) Issue Paper Smuggling of Migrants by Sea, 
https://www.unodc.org/documents/humantrafficking/Migrant-Smuggling/Issue-Papers/Issue_Paper__Smuggling_of_Migrants_by_Sea.pdf, citations

Zhang, S. X. (2008). Chinese Human Smuggling Organizations families, Social Networks, and Cultural Imperatives, Stanford University Press. 